\title{
Purification, crystallization, and X-ray crystallographic analysis of Acetolactate synthase from Hydrogenobacter thermophilus
}

\author{
Ji-Won Kim and Jeong-Sun Kim* \\ Department of Chemistry, Chonnam National University, Gwangju 61186, Republic of Korea \\ *Correspondence: jsunkim@chonnam.ac.kr
}

Acetolactate synthase (ALS) catalyzes the chemical reaction in plants and microorganisms that converts two pyruvate molecules to an acetolactate molecule and a carbon dioxide. To confer change on its substrate specificity for one carbon chemicals, structural study was initiated. For this, the recombinant ALS protein from Hydrogenobacter thermophilus (HtALS) was expressed in Escherichia coli, and homogeneously purified. The purified HtALS protein was crystallized from the precipitant composed of $0.3 \mathrm{M}$ Ammonium sulfate, $0.1 \mathrm{M}$ Sodium cacodylate $(\mathrm{pH} 6.5)$, and $18 \%(\mathrm{w} / \mathrm{v})$ polyethylene glycol 4000. Diffraction data was collected to $2.4 \AA$ resolution. The crystal belongs to the primitive orthorhombic $\mathrm{P} 2_{1} 2_{1} 2_{1}$ space group with unit-cell parameters $a=75.24 \AA, b=76.62 \AA, c=194.69 \AA$, and $\alpha=\beta=\gamma=90^{\circ}$. There are two HtALS molecules in the asymmetric unit.

\section{INTRODUCTION}

One carbon chemicals, such as methane, methanol, formaldehyde, and carbon dioxide, are easily diffused into air. They are also regarded as major chemicals for evoking greenhouse effects and global warming (Nordhaus, 1991). Even though plants and some algae catalyze a reaction for the incorporation of carbon dioxide into large molecules (Merrett and Lord, 1973), an enzyme that directly introduces a covalent bond between two one carbon chemicals is seldom found in nature.

Recently, a biological process for the conversion of formaldehyde into chemicals of two or three carbons is being attempted by using non-natural enzymes. Formolase is a modified enzyme of benzaldehyde lyase (BAL), and produces glycolaldehyde and dihydroxyacetone from formaldehydes (Siegel et al., 2015). A glycolaldehyde synthase is also a modified version of benzoylformate decarboxylase (BFDC), and converts two formaldehydes into a glycolaldehyde (Lu et al., 2019). These two enzymes commonly require a cofactor of thiamine diphosphate (ThDP). Even though it is rather obscure how the way in which they aid the formation or breakdown of covalent bonds between two carbon atoms, it is generally accepted that carbanion formation of a ThDP cofactor by the glutamate residue of an enzyme initiates the chemical reaction (Breslow and McNelis, 1959), implicating that other ThDP-dependent enzymes might be developed as a biocatalyst for the conjugation of one carbon chemicals.

Acetolactate synthase (ALS), which is also known as acetohydroxy acid synthase, catalyzes the chemical reaction that converts two pyruvate molecules to an acetolactate molecule, and releases a carbon dioxide molecule as a by-product. The reaction requires three cofactors of flavin adenine dinucleotide
(FAD), ThDP, and $\mathrm{Mg}^{2+}$. ThDP in the ALS enzyme is activated as it is deprotonated by glutamate, which generates an anion at the $\mathrm{C} 2$ atom between the sulfur atom and the nitrogen atom of the thiazolium ring of ThDP. Then, this carbanion acts as a nucleophile that attacks the carbonyl carbon of substrate (Breslow and McNelis, 1959). In the ALS-catalyzed reaction, the first pyruvate is decarboxylated by this attack, and the remnant is covalently bound to ThDP. Since this adduct also possesses a carbanion, its conjugation with the second pyruvate can proceed. The last reaction step is helped by the FAD cofactor, which provides an electron to give off the final product, (2S)-2acetolactate.

The suggested catalytic mechanism of ALS is very similar to that of BFDC itself and that of BAL, except for the last reduction by FAD. Comparison of the known structures of ALS to those of BAL and BFDC reveals the presence of close structural relationships between these enzymes, suggesting that ALS might also be developed as an enzyme for the formation of a covalent bond between two carbon atoms, like other ThDP-dependent enzymes. Therefore, the increased structural information of ALS is expected to contribute to developing a biocatalytic system for converting one carbon chemicals into more than two carbon carrying chemicals.

In this study, ALS from Hydrogenobacter thermophilus (HtALS) (Kawasumi et al., 1984) has been targeted for an enzyme candidate for converting one carbon chemicals. Since minute structural information at the molecular level may lessen trialand-error for variation of the substrate specificity of an enzyme, elucidation of the three-dimensional structure of HtALS has been initiated. For this, the codon-optimized HtALS-encoding gene was cloned into a bacterial expression plasmid. After heat 
treatment, the expressed recombinant protein was affinitypurified to high purity, and the purified protein was highly concentrated. The recombinant HtALS protein was successfully crystalized, and its X-ray diffraction data was collected. The electron density calculated by molecular replacement is enough to trace most residues of the molecule.

\section{RESULTS AND DISCUSSION}

The codon-optimized gene encoding the recombinant HtALS was synthesized, and subsequently cloned into the pProEx HTa

TABLE 1 I Protein production information

\begin{tabular}{ll}
\hline Source organism & Hydrogenobacter thermophilus \\
\hline DNA source & Synthesized DNA (Cosmogenetech, Seoul, Korea) \\
\hline Cloning vector & Modified pProEX HTa \\
\hline Expression vector & Modified pProEX HTa \\
\hline Expression host & E. coli BL21(DE3) \\
\hline & MSYYHHHHHHDYDIPTTENLYFQGHMARKGADIVI \\
& ETLKEEGVEYIFGHPGGAIMEVYDALYRDGSIKHILT \\
& RHEQGAGHMAEGYKATGKVGVAMSTSGPGATNL \\
& VTAIADAYMDSVPVFITGQVPTHLIGNDAFQEVDIV \\
& GITRPITKHNFLVKRIEDLPMILRQAFYIAKTGRPGPV \\
& LVDIPKDITQKISDVEIPSLEEVKSSLPGYKPHTEGNP \\
& QQIKKAARLIAEAKRPVLYVGGGAVQAEAQKELVEL \\
Complete & AELMKVPVTITNMGKGAFPESHPLALHMLGMHGT \\
amino acid sequence & YYANMAVYNCDLLIAVGARFDDRVGKVEFAPQA \\
of the construct & SIIHIDIDPASISKNIVDVVIVGDVKVLRKLIEEIKKEG \\
produced (N-C) & AKLLYPEERQKWLEQIEKWKKLHPLTYRKSDKVIKP \\
& QYVIEEIWKVTKGDAIIATGVGQHQMWAMFYRYSF \\
& PRQFINSGGLGTMGFGLPAGIGAKIGRPEKEVFVID \\
& GDGSFMMTMQELITAVHYRVPVKIAIINNGYLGMVR \\
& QWQELFYEKRYAEVDLSIQPDFVKLAEACGAVGFR \\
& AEKPSEVREVLEEAMKVQRPVLDFHVREENVL \\
& PMVPAGKSYRDMILEDGKKGVEADTMYLVG \\
\hline
\end{tabular}

*Underlined amino acid sequence indicates an $\mathrm{N}$-terminal 6xHis tagging and the TEV cleavage sequence.

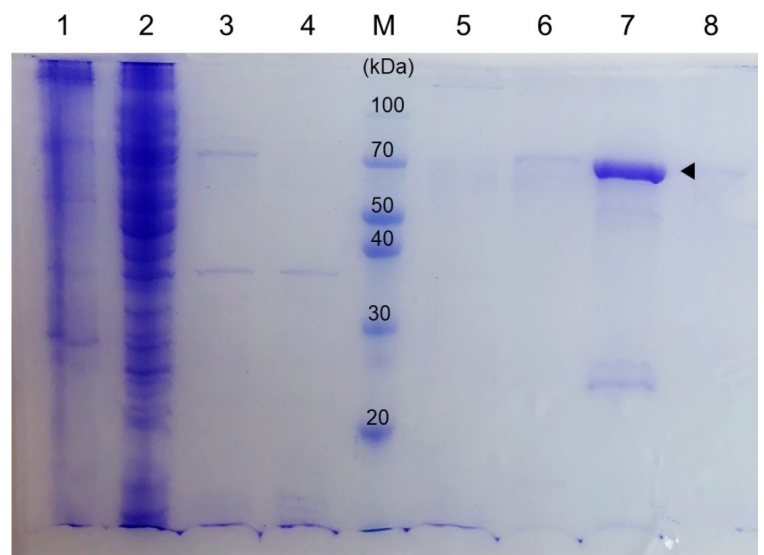

FIGURE 1 I SDS-PAGE analysis of the Ni ion affinity chromatography of HtALS. $12 \%$ (w/v) SDS-PAGE of the Ni affinity chromatography. Lane 1, Cell debris; lane 2, Precipitant fraction with thermal treatment; lane 3, Supernatant; lane 4, Unbound fraction; lane M, protein size marker; lanes $5-8$, Fractions eluted at 25,50,300,500 mM Imidazole concentration of buffer, respectively. The expected size of the recombinant HtALS protein is indicated by the black arrow. vector that contains an $\mathrm{N}$-terminal 6xHis-tagging cleavable with a tobacco etch virus (TEV) protease (Table 1). The expressed recombinant protein was initially purified by $\mathrm{Ni}$-ion affinity chromatography after heat treatment, and further with ion exchange chromatography (Figure 1). The purified HtALS protein was concentrated up to $5 \mathrm{mg} \cdot \mathrm{ml}^{-1}$ using Ultra centrifugal filter units (Merck Millipore) in the buffer consisting of $20 \mathrm{mM}$ Tris- $\mathrm{HCl}$ (pH 7.5) and 0.2 M NaCl.

Initial protein crystal screening was performed at $291 \mathrm{~K}$ using sparse-matrix crystal screening solutions of $\sim 1,000$. Yellowcolored crystals suitable for $\mathrm{X}$-ray diffraction (Figure 2) were obtained within 2 days at $291 \mathrm{~K}$ by mixing $0.5 \mu$ l of protein solution and $0.5 \mu \mathrm{l}$ of the reservoir solution including $0.3 \mathrm{M}$ Ammonium sulfate, $0.1 \mathrm{M}$ Sodium cacodylate $(\mathrm{pH} 6.5)$, and $18 \%$ (w/v) polyethylene glycol 4000 (Table 2).

For X-ray diffraction experiments, the obtained crystals were shortly immersed in the precipitant solution enriched with the cryo-protecting agents of $25 \%(\mathrm{w} / \mathrm{v})$ polyethylene glycol 4000 . The best diffraction data were collected to a resolution of 2.39 $\AA$ (Figure 3), and integrated and scaled using HKL2000 software package (Otwinowski and Minor, 1997). The crystal belongs to the primitive orthorhombic $\mathrm{P} 2{ }_{1} 2_{1} 2_{1}$ space group with unit cell

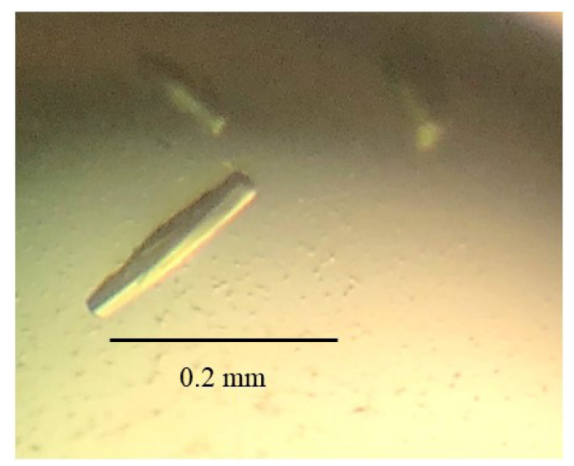

FIGURE 2 I A representative photograph of HtALS crystals. The crystal of HtALS protein was obtained from the reservoir solution consisting of $0.3 \mathrm{M}$ Ammonium sulfate, $0.1 \mathrm{M}$ Sodium cacodylate ( $\mathrm{pH} 6.5)$, and $18 \%$ $(\mathrm{w} / \mathrm{v})$ polyethylene glycol 4000 . The crystal was grown at $291 \mathrm{~K}$ within 2 days.

TABLE 2 I Crystallization

\begin{tabular}{ll}
\hline Method & Hanging-drop vapor diffusion \\
\hline Plate type & VDX ${ }^{\mathrm{TM}}$ Plate without sealant (24-well) \\
\hline Temperature $(\mathrm{K})$ & 291 \\
\hline $\begin{array}{l}\text { Protein concentration } \\
\left(\mathrm{mg} \cdot \mathrm{ml}^{-1}\right)\end{array}$ & 5 \\
\hline $\begin{array}{l}\text { Buffer composition of } \\
\text { protein solution }\end{array}$ & $20 \mathrm{mM}$ Tris- $\mathrm{HCl}(\mathrm{pH} 7.5), 0.2 \mathrm{M} \mathrm{NaCl}$ \\
\hline $\begin{array}{l}\text { Composition of } \\
\text { reservoir solution }\end{array}$ & $0.3 \mathrm{M} \mathrm{Ammonium} \mathrm{sulfate,}$ \\
\hline $\begin{array}{l}\text { Volume and ratio of drop } \\
18 \%(\mathrm{~W} / \mathrm{v}) \text { Polyethylene glycol 4000 }\end{array}$ \\
\hline \begin{tabular}{l} 
Volume of reservoir $(\mu \mathrm{l})$ \\
\hline
\end{tabular} & 200 \\
\hline
\end{tabular}


parameters $\mathrm{a}=75.24 \AA, \mathrm{b}=76.62 \AA, \mathrm{c}=194.69 \AA$, and $\alpha=\beta=$ $\gamma=90^{\circ}$ (Table 3 ). With two molecules in the asymmetric unit, the crystal volume per unit protein molecular weight corresponds with $2.19 \AA^{3} \cdot \mathrm{Da}^{-1}$, corresponding to $44 \%$ solvent in the crystal (Matthews, 1968).

The electron density of the HtALS crystal was obtained with molecular replacement (MR) by PHENIX (Adams et al., 2010), using $A$. thaliana acetohydroxy acid synthase structure (PDB ID 3E9Y, sequence identity $49 \%$ ) as the initial search model. The calculated electron density is clearly enough to trace most of the $\mathrm{C} \alpha$ atoms of the protein. Currently, preliminary structure refinement and model building are in progress. The diffraction data statistics is summarized in Table 3 . The crystal structure of HtALS is expected to provide molecular information that develops HtALS as a formaldehyde-converting enzyme.

\section{METHODS}

\section{Cloning, expression, and purification of HtALS}

The HtALS-expressing gene (ilvB) has 1,752 nucleotides that encode a polypeptide of 584 residues. The codon-optimized target gene was synthesized (Cosmogenetech, Seoul, Korea), and cloned into the pProEx HTa vector (Invitrogen) that allows the recombinant protein to be expressed with the $6 x \mathrm{His}$ TEV protease recognition site at the $\mathrm{N}$-terminus (Table 1). The recombinant plasmid was transformed into $E$. coli BL21(DE3) (Thermo Fisher Scientific), and was cultivated in Luria-Bertani media that was supplemented with $50 \mu \mathrm{g} \cdot \mathrm{ml}^{-1}$ of ampicillin at 310 $\mathrm{K}$ with shaking at $200 \mathrm{rpm}$. When the optical density at $600 \mathrm{~nm}$ reached 0.5 , the expression of the HtALS protein was induced at $291 \mathrm{~K}$ for 18.5 hours, after adding $0.1 \mathrm{mM}$ isopropyl $\beta$-D1 -thiogalactopyranoside into the cultural media. The cell was

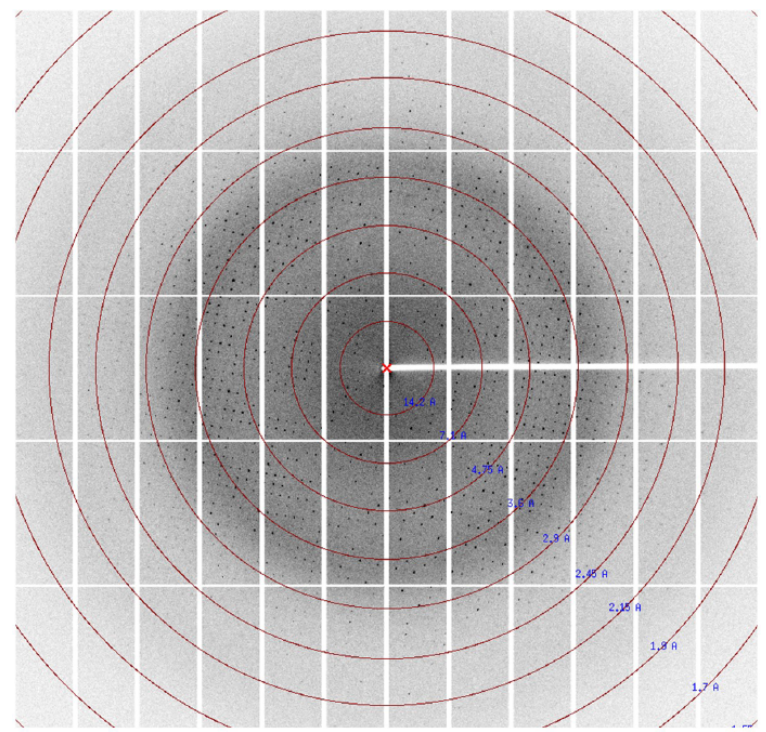

FIGURE 3 I A representative X-ray diffraction pattern of an HtALS crystal. The red circles and blue texts represent the resolution ranges. The crystal was exposed for $1 \mathrm{~s}$ with per-frame oscillation of $1^{\circ}$. harvested by centrifugation at 5,000 $\times g$ for $10 \mathrm{~min}$ at $277 \mathrm{~K}$. The collected cell was resuspended with buffer consisting of $20 \mathrm{mM}$ Tris- $\mathrm{HCl}(\mathrm{pH} 7.5), 0.5 \mathrm{M} \mathrm{NaCl}$, and $1 \mathrm{mM} \beta$-mercaptoethanol (buffer A), and disrupted by ultrasonicator. The cell debris was removed by centrifugation at $11,000 \times g$ for $30 \mathrm{~min}$ at $277 \mathrm{~K}$. The supernatant was heated at $353 \mathrm{~K}$ for $30 \mathrm{~min}$ in water bath. The denatured precipitation was removed by centrifugation, and only the supernatant was used for purification of the HtALS protein. The supernatant was purified initially by immobilized metal ion affinity chromatography (IMAC), using Ni-NTA resin (ELPIS, Daejeon, Korea) equilibrated with buffer $A$. The bound protein in the resin was eluted by a discontinuous gradient of 0-500 mM imidazole. To eliminate the $6 x \mathrm{His}$-tag, the target protein eluate was mixed with recombinant TEV protease, incubated at $291 \mathrm{~K}$ overnight, and dialyzed to remove the salt. After that, the TEV protease was removed by a second IMAC using Ni-NTA resin (Bio-Works) equilibrated with $20 \mathrm{mM}$ Tris- $\mathrm{HCl}(\mathrm{pH} \mathrm{7.5)}$ and $1 \mathrm{mM}$ $\beta$-mercaptoethanol (buffer B). HtALS protein was further purified by anion exchange chromatography using a $5 \mathrm{ml} \mathrm{HiTrap}{ }^{\mathrm{TM}} \mathrm{Q}$ column (GE Healthcare, Uppsala, Sweden). The target protein was eluted by a linear gradient from $0-1 \mathrm{M} \mathrm{NaCl}$ in buffer $\mathrm{B}$.

\section{Crystallization}

The purified HtALS was concentrated up to $5 \mathrm{mg} \cdot \mathrm{ml}^{-1}$ in a buffer consisting of $20 \mathrm{mM}$ Tris- $\mathrm{HCl}(\mathrm{pH} \mathrm{7.5)}$ and $0.2 \mathrm{M} \mathrm{NaCl}$ for crystallization (Figure 1). The protein concentration of HtALS was determined considering the molar extinction coefficient of 0.932 $\mathrm{M}^{-1} \cdot \mathrm{cm}^{-1}$ at $280 \mathrm{~nm}$. Initial crystallizing condition was obtained at $291 \mathrm{~K}$ using the sitting-drop vapor-diffusion method in 96-well crystallization plate (Corning, USA). A mixture of $0.3 \mu$ l of protein

TABLE 3 I Data collection statistics

\begin{tabular}{|c|c|}
\hline Data collection & HtALS \\
\hline Diffraction source & Beamline 11C, PAL \\
\hline Detector & Pilatus 6M \\
\hline Temperature (K) & 100 \\
\hline Rotation range per image $\left({ }^{\circ}\right)$ & 1 \\
\hline Exposure time per image (s) & 1 \\
\hline Total rotation range $\left(^{\circ}\right)$ & 180 \\
\hline Crystal-to-detector distance (mm) & 500 \\
\hline Space group & $\mathrm{P} 2{ }_{1} 2_{1} 2_{1}$ \\
\hline Unit cell parameters $\left(\AA{ }^{\circ}{ }^{\circ}\right)$ & $\begin{array}{l}a=75.24, b=76.62, c=194.69 \\
\alpha=\beta=\gamma=90\end{array}$ \\
\hline Wavelength $(\AA)$ & 0.97941 \\
\hline Resolution $(\AA)$ & $49.53-2.39(2.45-2.39)$ \\
\hline $\mathrm{R}_{\mathrm{sym}}{ }^{1}(\%)$ & $16.5(96.8)$ \\
\hline $1 / \sigma(I)$ & $8.4(1.9)$ \\
\hline Completeness (\%) & $99.3(93.9)$ \\
\hline Redundancy & $6.4(5.9)$ \\
\hline
\end{tabular}

${ }^{1}$ Rsym $=\sum_{h k l} \sum_{j}\left|I_{j^{-}}<I>\right| / \sum_{h k l} \sum_{j} I_{j}$, where $\mathrm{I}$ is the observed intensity of an individual reflection, and $<1>$ is the mean intensity of reflection.

The numbers in parentheses are from the highest resolution shell. 
solution and $0.3 \mu \mathrm{l}$ of protein drop was placed in each well of the plate, and was equilibrated with $55 \mu \mathrm{l}$ of reservoir solution at $291 \mathrm{~K}$. The initial conditions were obtained from a precipitant solution No.32 of MCSG-1T (Microlytic North America Inc., Massachusetts, USA), which contains $0.2 \mathrm{M}$ Ammonium sulfate, $0.1 \mathrm{M}$ Sodium citrate: $\mathrm{HCl}(\mathrm{pH} 5.6)$, and $25 \%(\mathrm{w} / \mathrm{v})$ polyethylene glycol 4000. This condition was further optimized by changing the buffer $\mathrm{pH}$, precipitant concentration, and salt concentration. The best crystals (Figure 2) were grown in $0.3 \mathrm{M}$ Ammonium sulfate, $0.1 \mathrm{M}$ Sodium cacodylate $(\mathrm{pH} 6.5)$, and $18 \%(\mathrm{w} / \mathrm{v})$ polyethylene glycol 4000 using hanging-drop vapor-diffusion method at $291 \mathrm{~K}$, where $0.5 \mu \mathrm{l}$ protein and $0.5 \mu \mathrm{l}$ precipitant were mixed and equilibrated with $200 \mu \mathrm{l}$ precipitant solution (Table 2).

\section{X-ray diffraction data collection and processing}

The obtained HtALS protein crystals were immersed shortly in the precipitant solution enriched with the cryo-protecting agents of $25 \%(\mathrm{w} / \mathrm{v})$ polyethylene glycol 4000 , and placed in the flowing $100 \mathrm{~K}$ nitrogen gas system. The X-ray diffraction data set of the HtALS protein crystal of 180 frames was collected using the Pilatus $6 \mathrm{M}$ detector at beamline $11 \mathrm{C}$ of the Pohang Light Source III (PLS III) at the Pohang Accelerator Laboratory (PAL, Pohang, Korea), with the per-frame oscillation of $1^{\circ}$, per-frame exposure of $1 \mathrm{~s}$, and the crystal-to-detector distance of $500 \mathrm{~mm}$ (Figure 3). The indexing, integration, and scaling of HtALS were conducted with the HKL-2000 suite (Table 3). The experimental electron density of the HtALS crystal was determined by the MR method in the PHENIX suite, using the structure of acetohydroxy acid synthase from $A$. thaliana (PDB ID 3E9Y) as a model.

\section{ACKNOWLEDGEMENTS}

We would like to thank Suk-Youl Park at beamline MX11C of the Pohang Accelerator Laboratory in Korea. This work was supported by a Basic Science Research grant (NRF Grant Number: 2019R1I1A3A01061866) of the National Research Foundation of Korea (NRF), funded by the Ministry of Education, Science and Technology of Korea (MEST).

\section{CONFLICT OF INTEREST}

The authors declare that there are no conflicts of interest.

Original Submission: Aug 26, 2021

Revised Version Received: Sep 13, 2021

Accepted: Sep 13, 2021

\section{REFERENCES}

Adams, P.D., Afonine, P.V., Bunkóczi, G., Chen, V.B., Davis, I.W., Echols, N., Headd, J.J., Hung, L.W., Kapral, G.J., Grosse-Kunstleve, R.W., McCoy, A.J., Moriarty, N.W., Oeffner, R., Read, R.J., Richardson, D.C., et al. (2010). PHENIX: a comprehensive Python-based system for macromolecular structure solution. Acta Crystallogr D Biol Crystallogr 66, 213-221.

Breslow, R., and McNelis, E. (1959). Studies on model systems for thiamine action. Synthesis of reactive intermediates, and evidence on the function of the pyrimidine ring. J Am Chem Soc 81, 3080-3082.

Kawasumi, T., Igarashi, Y., Kodama, T., and Minoda, Y. (1984). Hydrogenobacter thermophilus gen. nov., sp. nov., an extremely thermophilic, aerobic, hydrogen-oxidizing bacterium. Int $J$ Syst Bacteriol 34, 5-10.

Lu, X., Liu, Y., Yang, Y., Wang, S., Wang, Q., Wang, X., Yan, Z., Cheng, J., Liu, C., Yang, X., Luo, H., Yang, S., Gou, J., Ye, L., Lu, L., et al. (2019). Constructing a synthetic pathway for acetyl-coenzyme A from one-carbon through enzyme design. Nat Commun 10, 1378.

Matthews, B.W. (1968). Solvent content of protein crystals. J Mol Biol 33, 491-497.

Merrett, M.J., and Lord, J.M. (1973). Glycollate formation and metabolism by algae. New Phytol 72, 751-767.

Nordhaus, W.D. (1991). To slow or not to slow: the economics of the greenhouse effect. Econ J 101, 920-937.

Otwinowski, Z., and Minor, W. (1997). Processing of X-ray diffraction data collected in oscillation mode. Methods Enzymol 276, 307-326.

Siegel, J.B., Smith, A.L., Poust, S., Wargacki, A.J., Bar-Even, A., Louw, C., Shen, B.W., Eiben, C.B., Tran, H.M., Noor, E., Gallaher, J.L., Bale, J., Yoshikuni, Y., Gelb, M.H., Keasling, J.D., et al. (2015). Computational protein design enables a novel one-carbon assimilation pathway. Proc Natl Acad Sci U S A 112, 3704-3709. 